\title{
ANALYSIS OF ECONOMIC GROWTH IN TOURISM UNDER THE IMPACT OF TERRORISM AND OF THE WAVES OF REFUGEES
}

\author{
Gina Ionela Butnaru ${ }^{1 *}$, Marilena Mironiuc ${ }^{2}$, Carmen Huian ${ }^{3}$ \\ and Alina Petronela Haller ${ }^{4}$ \\ ${ }^{12) 33}$ Alexandru Ioan Cuza University of Iași, Romania \\ ${ }^{4)}$ Romanian Academy Branch of Iaşi - ICES, Gh. Zane, Romania
}

Please cite this article as:

Butnaru, G.I., Mironiuc, M., Huian, C. and Haller, A.P., 2018. Analysis of Economic Growth in Tourism Under the Impact of Terrorism and of the Waves of Refugees. Amfiteatru Economic, 20(Special No. 12), pp. 885-904.

\section{Article History}

Received: 14 August 2018

Revised: 10 September 2018

Accepted: 7 October 2018

DOI: $10.24818 / \mathrm{EA} / 2018 / \mathrm{S} 12 / 885$

\begin{abstract}
Tourism is an extremely complex phenomenon marked by major factors like the terrorist attacks and the refugees' invasion (the recent waves of migrants). This paper tests by empirical analyses if in the European Union countries, the gross domestic product in tourism reacts to the situations of crisis caused by the terrorist attacks and by the waves of refugees. The techniques used are $\sigma$ and $\beta$ convergence tests, combined with the deterministic sensitivity analysis. The sample consists of 26 European Union countries studied between 2000-2015 and 2000-2016, according to the available data. The results prove the prevalence of divergence, explicable by the existence of some countries, in the structure of the groups analysed, which have different contributions of gross domestic product in tourism to their overall economic growth. At the same time, a higher reaction of gross domestic product in tourism per capita is identified under the influence of the number of terrorism victims, compared to the incidence of the variation of the number of refugees. However, it cannot be stated that the two phenome $\mathrm{n}$ a lead to the general tendency of decrease of the gross domestic product in tourism per capita. On the contrary, there are occasional regressions of this indicator, which can be correlated only subsidiary with the crisis situations caused by terrorism and the waves of refugees.
\end{abstract}

Keywords: tourism, convergence, sensitivity analysis, terrorist attacks, refugees' invasion

JEL Classification: Z39, O11, O47, N94, E13

\footnotetext{
* Corresponding author, Gina Ionela Butnaru - gina.butnaru@ uaic.ro
} 


\section{Introduction}

Based on the studies performed, World Tourism Organisation (WTO) considers that the security problems in tourism represent dimensions of quality offered by a tourist service package. After the events from World Trade Centre in September 11th, 2001, the security problems in tourism were treated independently, because tourists are interested in safe destinations, which could offer them the comfort of their security. Some acts of violence were directed with or without intent against the tourists whose travel purpose was to spend their leisure time, events which had a negative impact on tourism industry.

Nowadays, the terrorist attacks are more frequent, and they occur in places which used to be safe in the recent past. France, England, Germany, Sweden, Norway, Italy, Spain, Greece are well-known tourist destinations in the European perimeter where terrorist attacks occurred. For example, between 1960 and 1980 in Europe only five terrorist attacks took place: two in 1960, one in 1974, and two in 1980, three in Italy, one in France, and one in Germany (Engene, 2011). The events escaladed in the last decades to an alarming intensity. The middle of 2000 marked the beginning of a delicate period for Europe with the attacks in Madrid and London (Gaub, 2017). Between 2013 and 2016, 30 terrorist attacks had been reported for Western Europe (France-10, Germany-6, Belgium-3, Denmark-3, UK-1, Sweden-1), among which 6 failed (France-4, Germany-2) (CAT, 2017). If we refer to the loss of tourism income, France for instance lost only in 2016750 million euro because of terrorist attacks (Kelly et al., 2016), and England recorded in the same year losses of approximately 1 billion pounds (Harris, 2016). It is normal for the terrorism to discourage potential tourists in choosing a tourist destination where a violent event occurred. Thus, we assist to a reconfiguration of the direction of tourist flows in the European Union (EU) towards the emergent countries.

Human tragedies dislocate the people from their birthplaces in the search of social and economic security. In Europe, we witness migration pressures from Syria, Afghanistan, and other areas with violent conflicts (CAT, 2017). The penetration on the European territory of a massive number of people with a different culture, who do not speak the language of the states they enter, with a different religion, led to the increase of the local level of risk. In this context, the EU is under the pressure of economic, social, and cultural challenges. The groups of refugees try to settle in developed European countries where the authorities can offer them comfort in the period of adaptation and socio-economic integration. It is not by chance that the countries chosen by the refugees are the same states which the tourists choose. Tourism is perceived as a form of temporary migration (Williams and Hall, 2002). Well-known tourist destinations attract such a high number of visitors that they are considered migration flows also when the purpose and the duration of the movement are different from the situation of permanent migration.

We consider that the two phenomena influence the economic growth in tourism, and this is the reason why we test by empirical analyses if in the EU countries the gross domestic product in tourism (GDPT) is affected by the terrorist attacks and by the waves of refugees. The research was performed for the member states of the UE for which there are official statistical data available, i.e. 26 of 28 members, divided by groups according to the degree they had been affected by terrorism/refugees in the period analysed. We reached the following conclusions: i) the convergence process of GDPT per capita was relatively slow and oscillating, alternating periods of convergence with those of divergence; ii)the 
amplitude of the sensitivity of GDPT per capita is much more obvious under the influence of the number of terrorism victims than under the one of the number of refugees.

This paper is structured in four parts. The first part is the review of the speciality literature. The second part includes first the methodological approaches regarding the convergence and the deterministic sensitivity analysis, then the testing of these aspects. The discussions on the research results are followed by the conclusions of the paper.

\section{Literature review}

\subsection{Tourism in the context of terrorist events from the perspective of official analysis}

Terrorism is a form of manifestation of organised crime. It developed and it increasingly affected the security of some of the holiday destinations preferred by tourists. There is an accumulation of psychological factors, and also of religious, political, social, or economic factors determining these events.

According to Global Terrorism Index 2015, terrorism continues to develop even if it is concentrated in a small number of countries (IEP, 2015). The data presented in this report show that in 2014 no EU member country identified itself in the group of those with maximum risk. The highest level of risk was recorded in the case of Great Britain (102 attacks), which was in the $28^{\text {th }}$ place with a score of 5.613 , seconded by Greece (26 attacks), in the $29^{\text {th }}$ place, with a score of 4.976 , and France (11 attacks), in the $36^{\text {th }}$ place, with a score of 4.553. In the case of Finland, Lithuania, Latvia, Romania, Slovakia, and Slovenia there was no risk of terrorist attacks, all these member states being in the $124^{\text {th }}$ place. The report gives Iraq a score of 10, being the country with the highest terrorist risk in the world. In 2014, the direct global costs of terrorism were 52.9 billion dollars, higher than in 2013, when they were 32.9 billion dollars. The amplitude of terrorism, both by number of victims and by number of attacks, lowered by $10 \%$ in 2015 compared to 2014, according to the data of Global Terrorism Index 2016 (IEP, 2016). Consequently, 2014 remains the bloodiest year in the statistics. According to the report Global Peace Index 2017, Europe remains the most pacifist area in the world, even if Southeast Europe is characterised by a higher political instability (IEP, 2017). Between 2007 and 2015, world peace regressed by $2.14 \%$. Mortality caused by wars increased by $408 \%$, and mortality caused by terrorism increased by $247 \%$. The first European Security Strategy stipulated that Europe was never so prosperous, secure, or free, however from 2003 the situation changed (Bendiek and Kaim, 2015). The fact that the terrorist attacks occur in places of conflict, and in countries where the security mechanisms and infrastructure are weak (Gunaratna, 2017) is infirmed by the reality of the last years. The attacks in France, UK, Germany, Sweden, and Belgium demonstrate that developed states, with performant security mechanisms and infrastructure, which are important tourist destinations are the main targets.

Despite the risks mentioned above, the tendencies regarding tourist activity in the EU are positive, illustrating an ascending evolution of this sector. The data reported by WTO confirm that in 2013 the EU attracted $40 \%$ of the world tourists, five EU member states being among the first ten world destinations: France, Spain, Italy, Germany, and UK (Kester, 2015). The same WTO report estimates an increase of the number of tourists in the EU by $2.1 \%$ until 2025, a lower increase than the world estimation, of 3.5\%. The emergent member countries, Bulgaria, Croatia, Hungary, Latvia, Lithuania, Poland and Romania, 
will register growth rates of tourist flows by $2.7 \%$ annually, until 2025 . The ascending tendencies are supported by the reduction of the costs of transportation, by the technological and communicational evolution (Yeoman, 2011).

\subsection{Tourism in the context of terrorist events from the perspective of scientific analyses}

The problem of terrorism was and still is much analysed, including from the perspective of its influence on the tourist sector, in scientific papers which involved rigorous research on this topic. Analysing the relationship between tourism and terrorism, Alkier, Radović and Lipovac (2016) consider that personal safety and sense of security in a country represent important factors in choosing a tourist destination. According to Sandler and Enders (2008), the attacks from the tourist areas, airports, hotels, points of tourist interest, or means of transportation determine tourists to associate a high risk to their holidays. The effects of the terrorist actions on the prices of tourist services were studied by Gazopoulou (2011) in the particular case of Greece. The conclusion of this study was that in certain periods, the terrorist attacks discouraged tourists to visit Greece.

Baker (2014) considers tourist sector as successful, but not safe from the terrorism effects. $\mathrm{He}$ is highlighting the fact that the terrorist attacks have never been as powerfully manifested as at the beginning of $21^{\text {st }}$ century. In the case of the well-known tourist countries, the terrorist risks affect the image of the area and the tourist industry as a whole as a result of the decrease in demand. Mass-media amplifies the phenomenon in a manner that the risks perceived escalate the reality regarding the attitude towards a certain destination. Schneider, Tillman and Meierrieks (2011) consider that terrorism and massmedia have a symbiotic connection. The influence of terrorism on economy is considerable, according to Vovk (2015), who highlights a psychological effect of terrorism called the adverse learning effect. People remember the painful memories of a terrorist attack.

Peterman, Revermann and Scherz (2005), in their research studies, consider that the future of tourist sector may depend on the amplitude of the associated risks. An unforeseen event redirects the tourist flows, and this influences the economic development of the tourist areas involved (Williams, 2012). Risks associated with tourist activity are also commercial, institutional, personal- specific to individual tourists, climate-related, or associated with epidemics (Stetić, 2012). In addition, there are natural disasters, managerial crises, terrorism, and organised crime (Robertson et al., 2006). According to Karl şi Schmude (2017), generally there are five major risks associated with tourism: terrorist attacks, natural disasters, epidemics, social instability and political instability.

\subsection{Tourism in the context of the refugee crisis}

Being travellers, tourists are in fact migrants who, for a certain period of time, leave their places to move - or to migrate - towards another destination, for different purposes (Leitão and Shahbaz, 2012; Tătăruşanu, 2016). Rode (2008) consider that the prototypical tourist's motivation to travel is reduced to consumption, but the range of motivations has been recently extended to existential or spiritual research, symbolic capital, cultural representations, desire of movement and adventure, historical relations, common language, and education (Tranos, Gheasi and Nijkamp, 2012). The flow of people moves towards the 
functional markets when there is an economic growth, and this depends on the orientation of the factors of production (Bakens and Nijkamp, 2010).

Most of the migrants do not travel without previously getting informed regarding the place, the society, and the culture of the country they go to. The presence of groups of foreigners is the effect of mass migration, phenomenon which the EU has been confronted with lately, with a peak in 2015, when the number of refugees doubled compared to 2014, especially in Germany, Hungary and Sweden (Aiyar et al., 2016). Hungary was preferred due to its geographical position, while Germany, France, UK and Sweden were preferred for their economic conditions.

Regarding the refugees' origin, the same authors state that they do not come only from conflict areas, but also from the Balkans area. Fargues (2015) analysed the composition of the flows of refugees who entered Europe in 2015 by Greece and Italy, realising that they changed their composition from the point of view of migrants' nationality. Taking into account that the phenomenon is alarming, the European countries took measures to reduce the flow of refugees. For example, after the elevation of a wire fence at the borders with Serbia and Croatia in the autumn of the year 2015, the number of refugees who entered the European territory through Hungary lowered (Benvenuti, 2017). Aiyar et al. (2016), in the study The Refugee Surge in Europe: Economic Challenges, estimate that the short-term impact of the flows of refugees is that the number of the population will grow between 2015 and 2017 by $0.15 \%$. On average term, the impact will be higher, and it will depend on the level of integration of the refugees on the labour market with an advantage for the people with a higher level of education (de la Rica, Glitz and Ortega, 2013). Crawley et al. (2016) mention the same causes for the increase of the flows of refugees towards Europe.

Starting especially with 2015 , the EU is in the situation to rethink its economic and social politics. The refugee crisis and the terrorist attacks, whose frequency increased in the European space, also influence tourism.

\section{Materials and methods}

The research intends to answer the question: are the recent waves of refugees and the terrorist attacks the factors causing the negative modification of the tourist activity of the states affected by these phenomena compared to the states unaffected towards which the tourist flows are redirected?

The question is answered by following two objectives:

- Testing the convergence ( $\sigma$ and $\beta$ ) with the help of the coefficient of variation and of the econometric modelling;

- Testing by the deterministic sensitivity analysis of the modality by which the terrorist attacks and the waves of refugees affect the economic growth in tourism in the EU states through the coefficients of elasticity of the number of international tourist arrivals, number of victims of terrorist attacks, average number of refugees and their implications regarding of gross domestic product (GDP).

In order to meet these objectives, we used a sample made of 26 of the $28 \mathrm{EU}$ member countries for the period between 2000 and 2015, because the most recent Index of Global Terrorism was published in 2016. It was at the basis of country grouping according to 
terrorism impact, for the last 16 years. In addition, since this index does not contain data for two of the EU28 member countries, Malta and Luxemburg, they were excluded from the analysis, leading to a final sample of 26 states. The impact of terrorism on tourist activities is measured by the number of victims (dead and wounded) after the attacks in each member country between 2000 and 2015. This indicator is collected from the Global Terrorism Database (2017), made by National Consortium for the Study of Terrorism and Responses to Terrorism (START), a department of Maryland University (USA) .After the analysis of the number of victims, the EU member states are divided in two categories, according to the median of the sample, as follows: countries not affected or less affected by terrorism (group A), and countries more affected by terrorism (group B). The number of refugees is taken from Eurostat statistics regarding international migration between 2000 and 2016, under the form of the number of people coming from non-member states requiring asylum in a member state. According to Eurostat (2017), asylum is a form of protection offered by a state on its territory, based on the principle of non-refoulement, and respecting the refugees' rights, recognised nationally and internationally. Based on the same mechanism, the countries are classified in two groups $(\mathrm{C}$ - with a lower number of refugees, and $\mathrm{D}-$ with a higher number of refugees). The structure of the four groups is presented in table no. 1 .

Table no. 1: Groups of member countries of the $\mathrm{EU}$ analysed according to the number of victims (NV) and the number of refugees (NR)

\begin{tabular}{|c|c|c|c|c|c|c|c|}
\hline Group A & NV & Group B & NV & Group C & $\begin{array}{c}\text { NR } \\
\text { (thousands) }\end{array}$ & Group D & $\begin{array}{c}\text { NR } \\
\text { (thousands) }\end{array}$ \\
\hline Sweden & 13 & Spain & 2647 & Finland & 85 & Germany & 2183 \\
\hline Austria & 12 & Great Britain & 1150 & Ireland & 76 & Greece & 220 \\
\hline Finland & 11 & France & 451 & Bulgaria & 74 & Austria & 440 \\
\hline Denmark & 10 & Germany & 134 & $\begin{array}{l}\text { Czech } \\
\text { Republic }\end{array}$ & 70 & Spain & 109 \\
\hline Hungary & 4 & Italy & 84 & Cyprus & 58 & Denmark & 113 \\
\hline Slovakia & 4 & Greece & 65 & Slovakia & 55 & Sweden & 686 \\
\hline Poland & 4 & Bulgaria & 43 & Romania & 21 & Poland & 137 \\
\hline Estonia & 2 & Latvia & 36 & Slovenia & 20 & Hungary & 317 \\
\hline Romania & 1 & Belgium & 29 & Lithuania & 6 & Great Britain & 697 \\
\hline Slovenia & 0 & $\begin{array}{l}\text { Czech } \\
\text { Republic }\end{array}$ & 27 & Portugal & 6 & Netherlands & 330 \\
\hline Portugal & 0 & Netherlands & 26 & Croatia & 4 & Belgium & 375 \\
\hline Lithuania & 0 & Croatia & 16 & Latvia & 2 & Italy & 519 \\
\hline Cyprus & 0 & Ireland & 14 & Estonia & 1 & France & 917 \\
\hline
\end{tabular}

Source: University of Maryland, 2017; Eurostat, 2017

To test the hypothesis of economy convergence of the 26 member-countries of the EU28, we are using the data regarding the GDP corresponding to tourism activities (gross domestic product in tourism - GDPT) collected from the reports of World Travel \& Tourism Economic Impact (WTTC, 2017). Beside the indicators already described, the sensitivity analysis uses the average number of international tourist arrivals between 2000 and 2015, taken from the database of World Bank - World Development (2017).

Convergence was initially analysed in Solow's studies in 1956 who defines it as a natural process based exclusively on market functionality (Solow, 1956). This neoclassical model considers that the investment in physical capital determines convergence. Sala-i-Martin (1996) introduced two indicators, $\sigma$ and $\beta$, the first showing the convergence or divergence tendency, and the second the convergence speed. The neoclassical model was subsequently 
modified and developed to explain the differences among countries, and the modality of their reduction according to factors like saving rate, population growth rate, labour mobility, migration, etc. Butnaru and Haller (2017) study the impact of sustainable rural tourism on the economy of the development regions of UK and Northern Ireland by using the method of $\sigma$ and $\beta$ convergence. In this case it was demonstrated, by analysing GDPT, that the convergence process performed slowly, and sustainable rural tourism influenced the development.

Testing $\beta$ convergence is performed by applying Baumol model (1986), described in equation 1 and modified by Dvoroková (2014) in equation 2. For $\sigma$ convergence we apply the indicator used by Iancu (2009) and presented in equation 3.

$$
\begin{aligned}
& \frac{1}{T}\left[\ln \left(y_{i, T}\right)-\ln \left(y_{i . t_{0}}\right)\right]=\alpha+\beta \ln \left(y_{i, t_{0}}\right)+\varepsilon_{t} \\
& \frac{1}{T} \ln \left(\frac{y_{i, T}}{y_{i, 0}}\right)=\alpha+\beta \ln \left(y_{i, 0}\right)+\varepsilon_{i} \\
& \sigma_{t}=\sqrt{\frac{1}{n} \sum_{i=1}^{n} \frac{\left(y_{i t}-\bar{y}_{t}\right)^{2}}{y_{t}}}
\end{aligned}
$$

where: $T$ is the time interval, $y_{i, T}$ is GDP in tourism (GDPT) per inhabitant of the country $i$ at the end of the period of time, and $y_{i, 0}$ is the same indicator at the beginning of the period of time, $\alpha$ is the constant of the equation, $\beta$ is the slope of the regression line, and $\varepsilon$ is the statistical error, $\mathrm{n}$ is the number of sample states, $y_{i, t}$ is GDPT per capita of the country $i$ in the year $t$ and $\bar{y}_{t}$ is average GDPT in the year $t$.

By a deterministic sensitivity analysis, more precisely by the calculation and interpretation of coefficients of elasticity, we will deduce the modality by which the variation of economic growth in tourism (GDPT per capita, as dependent variable $Y$ ) may be attributed to the successive variation of input parameters (average number of international tourist arrivals, average number of victims of terrorist attacks, average number of refugees, as independent variables $X$ ), in the time interval considered.In general, a coefficient of elasticity $\left(E_{Y / X}\right)$ expresses the relative variation of a dependent $(\Delta r Y)$ as a result of the variation by one percentage of the input parameter $(\Delta r X)$, in a time interval established, according to the equation 4 .

$$
E_{Y / X}=\frac{\Delta r Y}{\Delta r X}=\frac{\frac{Y_{t}-Y_{t-1}}{Y_{t-1}} \cdot 100}{\frac{X_{t}-X_{t-1}}{X_{t-1}} \cdot 100}=\frac{I Y-100}{I X-100}
$$

where: $t$ and $t-1$ are the current period and the period considered as reference in the calculation of relative modification of the variables analysed, $I Y$ is the index of the dependent variable, $I X$ is the index of the input parameter.

The high values of the coefficient of elasticity are the expression of a high level of sensitivity of the dependent variable at a less significant modification of the input 
parameters, situation associated with the presence of risk factors determining deviations among the expected/estimated results compared to their mean (Mironiuc, 2009).

\section{Results and discussion}

\section{1. $\beta$ and $\sigma$ convergence}

The results of the calculations are synthetically presented in table no. 2 for $\beta$ convergence evaluated on the sample countries.

Table no. 2: $\beta$ convergenceassessed according to the impact of terrorism, measured by the number of victims and according to the number of refugees

\begin{tabular}{l|r|r|r|r}
\hline & \multicolumn{1}{|c|}{ Group A } & Group B & Group C & Group D \\
\hline Constanta & 0.153 & 0.166 & 0.161 & 0.108 \\
\hline $\ln \left(\mathrm{GDP}_{\mathrm{it} 0}\right)$ & $-0.019(0.000)^{*}$ & $-0.021(0.000)^{*}$ & $-0.020(0.000)^{*}$ & $-0.013(0.000)^{*}$ \\
\hline $\mathrm{R}^{2}$ & 0.867 & 0.906 & 0.914 & 0.782 \\
\hline F test & $71.925(0.000)^{*}$ & $106.485(0.000)^{*}$ & $116.679(0.000)^{*}$ & $39.524(0.000)^{*}$ \\
\hline
\end{tabular}

(in the brackets are the values of sig.), ${ }^{*}$ significant at the level of $5 \%$

The validation of the statistic model used is performed by testing the regression hypotheses (Jemna, 2012). Kolmogorov-Smirnof test showed the normal distribution of the errors, while Durbin Watson test confirmed the non-correlation of the errors. White test showed the lack of heteroscedasticity, and T-test - a null mean of the errors. Due to the negative values of $\beta$ slope $(-0.019,-0.021,-0.020,-0.013)$, we can see that for the period analysed, the sample countries record $\beta$ convergence, with a relatively slow speed (the coefficient $\beta$ has low values), i.e. there is a reverse relationship between the growth rhythm of GDPT per capita and the initial level of GDPT per capita. $\sigma$ convergence model proposed by Iancu (2009) uses the coefficient of variation $\sigma_{t}$, which indicates the convergence level by measuring the dispersion of GDPT. As we can see in figures no. 1 and no. 2 and from Annex 1, the values obtained for $\sigma_{t}$ for the 4 groups of sample countries record a slight oscillation. As a result, we can see that the sample analysed recorded alternatively both convergence and divergence.

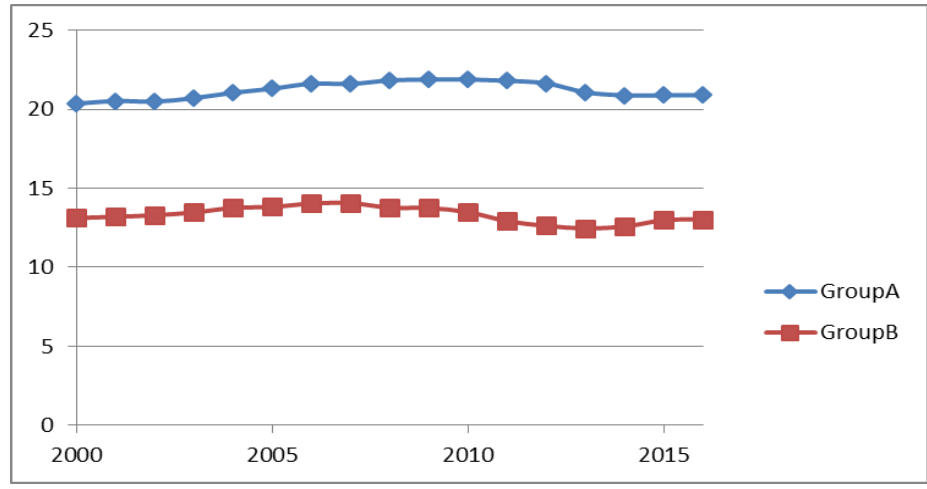

Figure no. 1: $\sigma$ convergence according to the number of victims of terrorism 


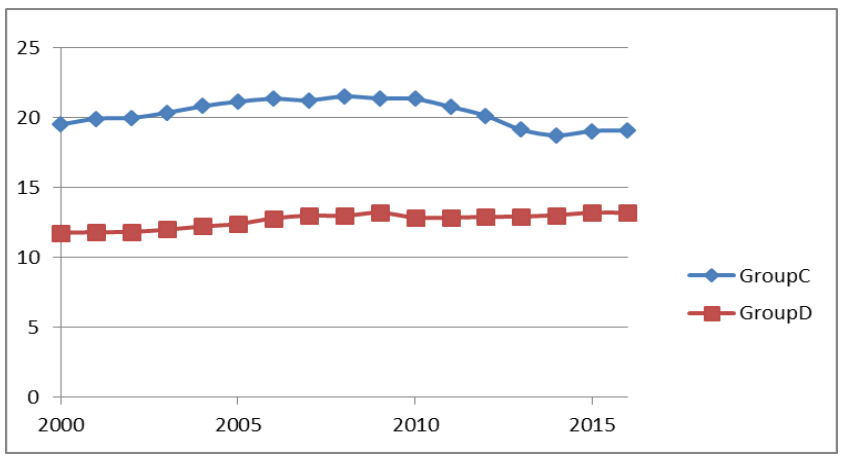

Figure no. 2: $\sigma$ convergence according to the number of refugees

The analysis of the countries grouped according to the number of terrorism victims highlights, for the group A, a higher alternation of the convergence periods (2001-2002; 2003-2004; 2006-2007; 2010-2013) with the divergence periods in terms of GDPT per capita. Among the countries included in the group B, the periods of convergence (2007-2013) and divergence processes are more compact. In the case of the countries grouped according to the criterion of waves of refugees, the degree of convergence is characterised by continuity between 20082014 , for the group C, while in the group D we can identify a higher degree of alternation between the convergence $(2007-2008 ; 2009-2011 ; 2015-2016)$ and divergence processes. In conclusion, we can state that among the EU countries from the groups analysed the divergence process regarding GDPT per capita is prevalent, and the convergence process could take place in a very slow rhythm. The situation could be considered normal, because these groups include the countries with different economic power.

The results of convergence are more relevant in the context of the analysis of the countries of each group according to the specificity of their tourist development and to their geographical location. The states from group A are heterogeneous from the point of view of economic development, and they belong to the second echelon of European tourism, some destinations being less attractive compared to others. Group A also includes the emerging European economies, characterised by a substantial development gap compared to the EU industrialised countries. These states barely consolidate their tourist image, they have an incomplete and deficient offer regarding service quality, in which the price-quality ratio situates under the expectancy of the visitors coming from developed countries. There are situations when low tourist attractiveness is the consequence of an informational deficit related to the culture and the opportunities offered by these destinations. Tourists might select the countries from the group A when the price plays an important role in making the decision to choose a destination, or when there are active factors involved, like terrorism, migration, extreme manifestations of the climate, etc. on the territory of the states of group B. Group A includes less tourist attractive countries, but safer ones.

Group B is mostly made of the European countries from the first tourist and transit echelon. The states are well integrated on the international tourist market, due to their culture and to the particularities of the tourist offer. For some of the countries in this group, the tourist sector has a significant share of GDP. Group B also includes transit countries, geographically situated at the intersection of the tourist air routes and roads. It is the status of developed economies, important tourist destinations and transit countries which attracts the manifestation of events associated to high risks like terrorism and migration. 
The economy of the countries with lower degree of attractiveness for the refugees, group C, is less developed compared to the EU industrial states, some being situated at relatively big geographical distances from the entrance gates to the community space. The refugees avoid the emergent European countries because the income is lower, the social protection system is not attractive, and the communities of co-nationals are almost inexistent.

Group D includes the European countries which are attractive for the refugees, with developed economy, and entrance channels on the European territory. The refugees remain on the territory of the entrance states, like Greece and Italy, or they try to get where regulations and economic conditions offered by the social protection system are satisfying, where there are consolidated communities of co-nationals, and where the society is open to multi-culturalism, without manifesting religious, cultural, racial or gender discrimination.

\subsection{Sensitivity analysis}

The result analysis from Annex 2 indicates, except for the year 2015, a reverse and prevalently negative relation between the variation of the number of terrorism victims and the average number of international tourist arrivals. The apparent relatively high increase of the number of terrorism victims in 2001/2000 (index 140\%), 2009/2008 (index 300\%), and 2015/2014 (index 1600\%) corresponds in absolute values to a low number of victims (2 people, 8 people, and 15 people), which did not significantly decrease the number of average international tourist arrivals (2.44\% in 2001/2000; 6.36\% in 2009/2008). Only in 2009, the decrease by $1 \%$ of the average number of international tourist arrivals, compared to the previous year, due to the increase of the average number of terrorism victims, corresponds to a decrease of average GDP in tourism per capita (E GDPT/T) by $0.96 \%$. The sensitivity amplitude of average GDP in tourism per capita at the dynamics of the average number of international tourist arrivals is higher $(5.68 \%)$ in the periods with decrease or absence of the average number of terrorism victims (2002-2008). The average GDPT per capita increased by $17.11 \%$ at the increase by $1 \%$ of the average number of international tourist arrivals, under the influence of the decrease by $55.56 \%$ of the average number of terrorism victims in 2008/2007. In 2015/2014, the ascending dynamics of the average number of terrorism victims does not negatively affect the average number of international tourist arrivals, nor the average GDPT per capita, instead it causes a slower evolution (figure no. 3).

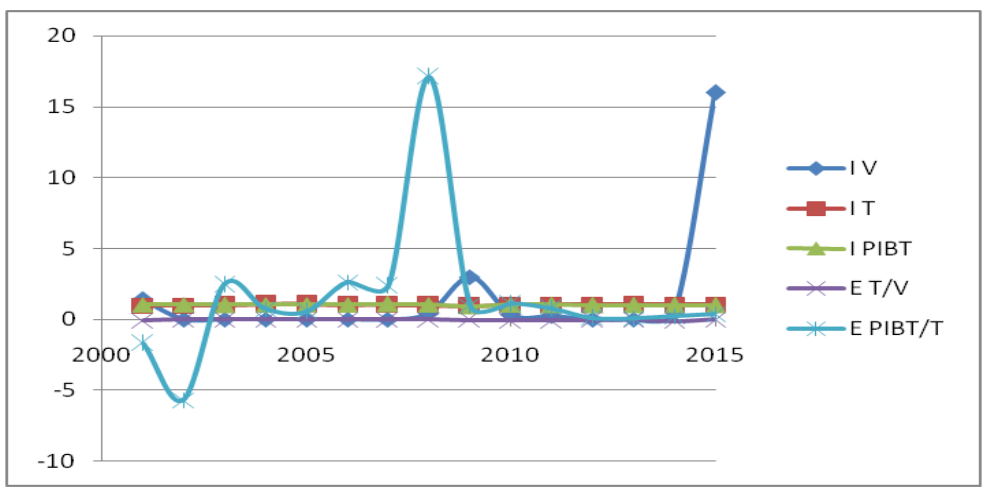

Figure no. 3: Sensitivity of GDPT at the variation of the number of tourists under the influence of terrorist attacks - Group A 
In the countries in group B, according to the data from Annex 3, the elasticity of the average number of international tourist arrivals in relation to the average number of terrorism victims $(\mathrm{E} T / \mathrm{V})$ expresses the negative relation between these two variables in nine of the periods analysed. Consequently, the increase by a percentage of the number of terrorism victims leads to a decrease by minimum $0.01 \%$ and maximum $0.19 \%$ of the average number of international tourist arrivals, and the decrease of the average number of terrorist attack victims increases the average number al international tourist arrivals by minimum $0.03 \%$ and maximum $0.10 \%$. This situation is not negatively influencing the average GDPT per capita in 2001 and 2008 which increases by $5.23 \%$, respectively by $0.71 \%$. However, in 2009 , the average GDPT per capita decreases by $1.27 \%$ under the influence of the decrease by $1 \%$ of the average number of international tourist arrivals, as an effect of terrorism victims. In 2009 there were 116 victims in the countries in group B compared to 95 in 2008 and 42 in 2010.

The sensitivity of the average GDPT (E GDPT/T) is lower and decreasing in 2006, 2010. 2011 and 2014. We can see that in six of the periods analysed the increase of the average number of terrorism victims does not lead to the decrease of the average international tourist arrivals, only to a lower rhythm of their increase. This can also be seen in the periods when the number of victims considerably increased, as in 2004 (index 1539.10\%), 2012 (index 315\%), 2013 (index 138.10\%) and 2015 (index 1100\%). Except for 2013, the slow dynamics of the average number of international tourist arrivals under the influence of terrorist attacks positively influences the average GDPT per capita. We can see in 2003 its increase by $18.30 \%$, corresponding to an increase by $1 \%$ of the average number of international arrivals (figure no. 4).

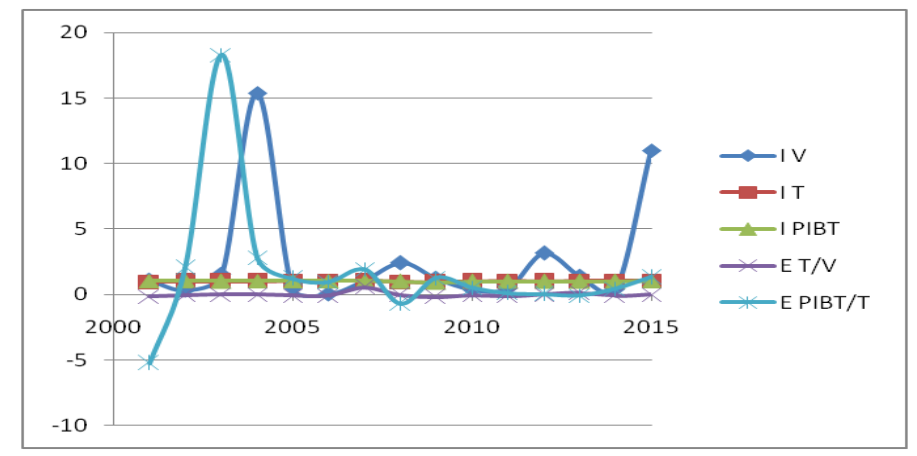

Figure no. 4: Sensitivity of GDPT at the variation of the number of tourists under the influence of terrorist attacks -Group B

Regarding the countries in group C (Annex 4), there are alternate positive and negative relations between the variation of the average number of refugees and the dynamics of the average number of international tourist arrivals. The increase of the average number of refugees by $1 \%$ determines the increase of the average number of international tourist arrivals in 2001, 2003, 2007, 2012, 2013, 2014 and 2015 (E T/R). However, the values of the coefficient of elasticity between these two variables is decreasing, which attests that the flow of international tourist arrivals increases very little, especially in the last years of the period analysed (2012-2015). The year 2009 is an exception, when, though the relation between the variables mentioned is positive, the decrease by $1 \%$ of the average number of refugees corresponds to the decrease of the average number of international arrivals by 
$1.04 \%$. Subsequently there are negative consequences on the average GDPT per capita, which decreases by $0.78 \%$ (E GDPT/R). We identify the negative relation between the average number of refugees, which at a decrease by $1 \%$ determines an increase, in general, under $1 \%$ of the average number of international tourist arrivals, in 2002, 2005, 2006 and 2008. Consequently, we deduce that regardless of the variation of the average number of refugees, there is an ascending tendency of the average flow of international tourist arrivals, which means that, for the group $\mathrm{C}$ of countries, this parameter was not affected by the waves of refugees. The general tendency of the average GDPT per capita is growing, except for 2012 and 2013, when the decrease is insignificant (by $0.0859 \%$ and $0.0849 \%$ ) at an increase by $1 \%$ of the average number of international tourist arrivals (figure no. 5).

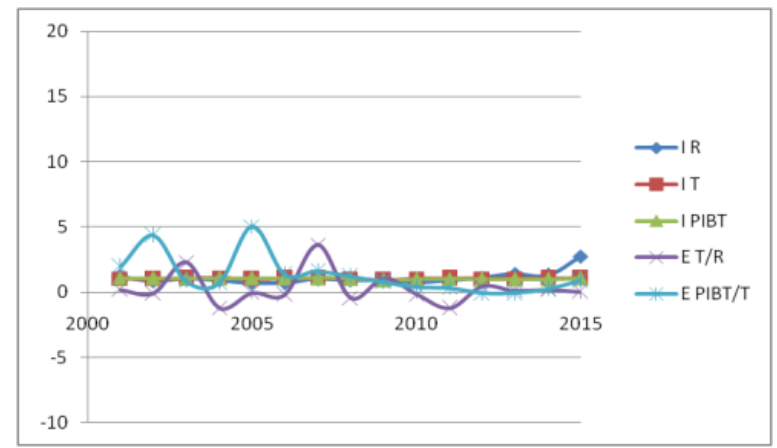

Figure no. 5: Sensitivity of GDPT to the variation of the number of tourists under the influence of the waves of refugees - Group $C$

For the countries in group D (Annex 5), we notice the prevalence of the positive relation between the average number of refugees and the average flow of international tourist arrivals in seven years from the period analysed. The values of the coefficient of elasticity between these two variables (E T/R) explain the low increase of the flow of average international tourist arrivals, especially in 2012-2015. The relation between the variables mentioned above determines increasing but weaker variations of the average GDPT per capita (E GDPT/R) in the last years of the period analysed, explained by: though numerically the average international tourist arrivals amplify, their power of acquisition decreases in the period of crisis and post-crisis, or, in fact, the refugees increase artificially the average number of international arrivals, because in reality they do not come with tourist purposes. The sensitivity of the average number of international arrivals at the increase by $1 \%$ of the average number of refugees was relevant $(6.22 \%)$ in 2010 , without being reflected in a similar growth of the average GDPT per capita $(1.41 \%)$. We can also identify the negative relations between the average number of the refugees, which is decreasing, and the increase of the average number of international tourist arrivals in 2004, 2005, 2006, which determines the increase, however low, of the average GDPT per capita. The years 2001, 2008 and 2009 indicate the increase of the average number of refugees simultaneously with the decrease of the average number of international tourist arrivals, however with a favourable impact on the average economic growth in tourism per capita in 2001 and 2008, and negative in 2009 (figure no. 6). 


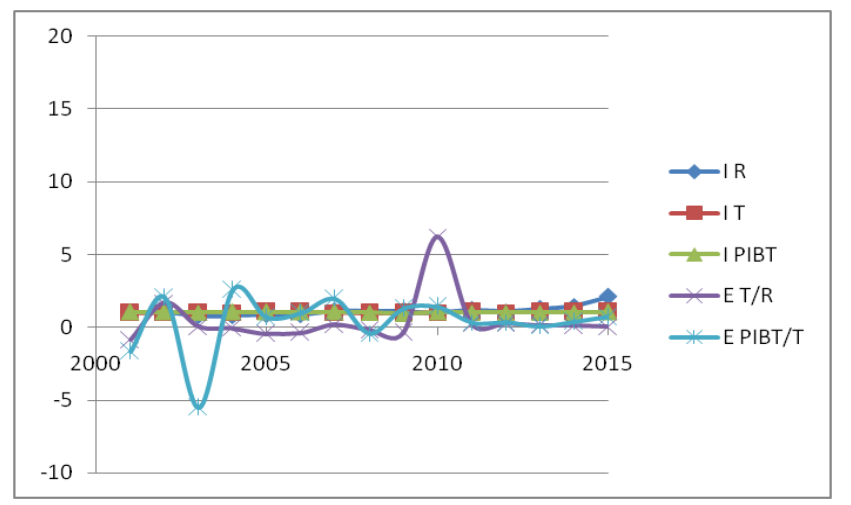

Figure no. 6: Sensitivity of GDPT to the variation of the number of tourists under the influence of the waves of refugees - Group D

\section{Conclusions}

In this study we analysed, theoretically and empirically, the influence of terrorism and the refugees' invasion on the economic growth in tourism in the EU. The specificity of this paper consists in the combination of convergence analysis with deterministic sensitivity analysis to find an answer to the question indicated in the research methodology. The empirical component of the paper initially involved the division of the European states in four groups: A (countries little affected by terrorism), and B (countries strongly affected by terrorism), $\mathrm{C}$ (countries attracting low flows of refugees), and D (countries attracting high flows of refugees) respectively.

The testing of convergence ( $\sigma$ and $\beta$ ) according to the criterion of average GDPT per capita was performed with the help of the coefficient of dispersion and econometric modelling, according to the terrorism impact(number of victims), and the waves of refugees (their number). The sample analysed recorded convergence and divergence alternatively, with prevalence of the latter. This result can be considered normal, because the structure of the groups studied includes countries with different contributions of GDPT per capita to the economic growth.

The sensitivity analysis indicates the decrease or the slower increase of the average number of international tourist arrivals according to the increase of the average number of terrorism victims. It results that the risk of being a potential terrorist target generates a quick negative response from the tourist service consumers. The decrease of the average number of international tourist arrivals under the incidence of terrorist attacks determines a higher sensitivity of average GDPT per capita in the countries strongly affected by terrorism (higher values of the coefficients of elasticity for the countries in group B compared to the countries in group A). Despite these situations, there are rare cases when the average GDPT per capita decreases due to the influence of the variation of the average number of international arrivals under the pressure of terrorist attacks. This conclusion agrees with the deductions of other authors (Llorca-Vivero, 2008), who state that there is a minor impact of terrorism on the economic growth, especially in the developed countries. The decrease of average GDPT per capita can be seen in 2009 for both groups of countries (A and B), and 
in 2013 only for the countries in group B. In 2015, though the average number of terrorism victims increased considerably for both groups of countries (A and $B$ ), the average number of international tourist arrivals did not decrease, and it did not affect the average economic growth in tourism, probably also as an effect of intensification of international security measures and policies.

Regardless of the variation of the average number of refugees, we can see a growing tendency of the average number of international tourist arrivals in the countries in group $\mathrm{C}$, which means that this parameter was not affected by the waves of refugees. For the countries in group D, the average increase of the number of international tourist arrivals was prevalently due to the arrival of the waves of refugees, who in fact did not have tourist purposes, which is reflected by the very little increase of the average GDPT per capita.

The comparative analysis of the terrorist and migration impact by the arrival of the waves of refugees on the economic growth in tourism (GDPT) confirms that the amplitude of the sensitivity of GDPT per capita is much more obvious under the influence of the number of terrorism victims than under the incidence of the variation of the number of refugees. The amplitude with which this indicator reacts in the countries affected by terrorism and by the waves of refugees (groups B and D) is higher than the elasticity manifested by the same indicator in the countries less affected by these two phenomena (groups A and C). However, we cannot state that the general tendency is the decrease of the average GDPT per capita due to the two phenomena. We rather ascertain that there is an occasional decrease which may be correlated with the crisis situations caused by the two factors, or a slower economic growth in tourism.

According to the research results, terrorism remains a major risk for tourism, and institutional measures are necessary at national and international level. The refugee phenomenon proves to have no direct or negative influence on tourist activity, therefore we cannot include it in the category of risks associated directly with tourism results. A study extended on a more representative sample, being more complex by the inclusion in the models of other specific indicators, performed on a period allowing the panel analysis, could highlight more precisely the influence of the flow of refugee son tourism activity. Consequently, this paper represents a starting point in the authors' future research preoccupations based on the risk analysis of the phenomena of migration and of demographic dynamics on the tourist sector.

\section{References}

Aiyar, S., Barkbu, B., Batini, N., Berger, H., Detragiache, E., Dizioli, A., Ebeke, C., Lin, H., Kaltani, L., Sosa, S., Spilimbergo, A. and Topalova, P., 2016. The Refugee Surge in Europe: Economic Challenges. IMF Staff Discussion Notes. [pdf] Available at: <https://www.imf.org/external/pubs/ft/sdn/2016/sdn1602.pdf> [Accessed 27 May 2017].

Alkier, R., Nimac, K.R. and Lipovac, S., 2016. Security in European Tourism with Particular Attention Paid to the Republic of Croatia. Proceedings Book [online] Available at: <https://icesos.ibu.edu.ba/wp-content/uploads/2017/01/ICESoS2016-Proceedings BookFullBook1.2PRINT.pdf $>$ [Accessed 30 September 2018].

Bakens, J. and Nijkamp, P., 2010. Lessons from Migration Impact Analysis, Estudos Regionais, [online] Available at: <http://www.apdr.pt/siterper/numeros/RPER24/ 24.1.pdf> [Accessed 30 September 2018]. 
Baker, D.M.A., 2014. The Effects of Terrorism on the Travel and Tourism Industry. International Journal of Religious Tourism and Pilgrimage, 2(1), pp. 58-69.

Baumol, W., 1986. Productivity Growth, Convergence, and Welfare: What the Long-Run Data Show. The American Economic Review, 76(5), pp. 1072-1085.

Bendiek, A. and Kaim, M., 2015. New European Security Strategy - The Transatlantic Factor. [pdf] German Institute for International and Security Affairs - SWP Comments 34. Available at: <https://www.swp-berlin.org/fileadmin/contents/products/comments/ 2015C34_bdk_kim.pdf> [Accessed 27 June 2017].

Benvenuti, B., 2017. The Refugee Debate in Central and Estern Europe: Can the EUTurkey Deal Survive without Intra EU Convergence on Relocation and Resettlement?. [pdf] Intituto Affari Internazionali. Available at: <http://www.iai.it/sites/default/ files/iai1705.pdf > [Accessed 20 June 2017].

Butnaru, G.I. and Haller, A.P., 2017. Perspective of Sustainable Rural Tourism in the United Kingdom of Great Britain and Northern Ireland (UK): Comparative Study of $\beta$ and $\sigma$ Convergence in the Economic Development Regions. Sustainability, 9(4), p. 525 .

Center for the Analysis of Terrorism (CAT), 2017. Terrorist Attacks, Failed Attacks and Plots in the West linked to the Syrian - Iraqi Context (2013-2016). [pdf] Available at: <http://cat-int.org/wp-content/uploads/2017/04/Terrorist-attacks-Report-2013-2016.pdf> [Accessed 17 September 2018].

Crawley, H., Düvell, V, Jones, K., McMahon, S. and Sigona, N. 2016. Destination Europe? Understanding the Dynamics and Drivers of Mediteranean Migration in 2015. MEDMIG Final Report. [pdf] Available at: <http://www.medmig.info/wp-content/uploads/2016/12/ research-brief-destination-europe.pdf $>$ [Accessed 7 June 2017].

De la Rica, S., Glitz, A. and Ortega F. 2013. Immigration in Europe: Trends, Policies and Empirical Evidence. IZA Discussion Paper 7778.

Dvoroková, K., 2014. Sigma Versus Beta-convergence in EU28: do they lead to different results?, Mathematical Methods in Finance and Business Administration, [online] Available at: <http://www.wseas.us/e-library/conferences/2014/Tenerife/ECONMATH/ ECONMATH-13.pdf> [Accessed 21 November 2016].

Engene, O.J., 2011. The Extreme Right in West European Terrorism.[pdf] CIR. Available at: <http://ps.au.dk/fileadmin/site_files/filer_statskundskab/subsites/cir/pdf-filer/ The_Extreme_Right_in_West_European_TerrorismJAN_OSKAR_ENGENE.pdf> [Accessed 17 september 2018].

Eurostat, 2017. Asylum statistics, [online] Available at: <http://ec.europa.eu/eurostat/ statistics-explained/index.php/Asylum_statistics> [Accessed 25 June 2017]

Fargues, P., 2015. 2015: The Year We Mistook Refugees for Invaders. [pdf] Migration Policy Center. Available at: <http://cadmus.eui.eu/bitstream/handle/1814/38307/ Policy_Brief_2015_12.pdf> [Accessed 27 June 2017].

Gaub, F., 2017. Trends in terrorism. [pdf] European Union Institute for Security Studies (EUISS). Available at: <https://www.iss.europa.eu/sites/default/files/EUISSFiles/ Alert_4_Terrorism_in_Europe_0.pdf > [Accessed 17 september 2018].

Gazopoulou, H., 2011. Assessing the Impact of Terrorism on Travel Activity in Greece. [pdf] Bank of Greece, Economic Research Department - Special Studies Division. 
Available at: <http://www.bankofgreece.gr/BogEkdoseis/Paper2011127.pdf> [Accessed 27 June 2017].

Gunaratna, R., Harrison, J., Ramakrishna, K., Reinares, F. and Sloan, S., 2017. Global Threat Forecast. Counter Terrorist Trends and Analyses RSIS, 9(1), pp. 3-11.

Harris, T., 2016. London's Preparedness To Respond To A Major Terrorist Incident. [pdf] Available

<https://www.london.gov.uk/sites/default/files/londons_preparedness_to_respond_to_a_ major_terrorist_incident_-_independent_review_oct_2016.pdf $>$ [Accessed 17 september 2018].

Iancu, A., 2009. Convergenţa reală. [pdf] Bucureşti: INCE-CIDE. Available at: $<$ http://www.studii-economice.ro/2009/seince090701.pdf> [Accessed 12 May 2017].

Institute for Economics \& Peace, 2015. Global Terrorism Index 2015. [pdf] Available at: $<$ http://economicsandpeace.org/wp-content/uploads/2015/11/Global-Terrorism-Index2015.pdf > [Accessed 2 June 2017].

Institute for Economics \& Peace, 2016. Global Terrorism Index 2016. [pdf] Available at: $<$ http://economicsandpeace.org/wp-content/uploads/2016/11/Global-Terrorism-Index2016.2.pdf.> [Accessed 2 June 2017].

Institute for Economics \& Peace, 2017. Global Peace Index 2017. [pdf] Available at: $<$ http://visionofhumanity.org/app/uploads/2017/06/GPI-2017-Report-1.pdf> [Accessed 27 June 2017].

Jemna, D., 2012. Econometrie. Iaşi: Sedcom Libris.

Karl, M. and Schmude, J., 2017. Understanding the role of risk (perception) in destination choice: A literature review and synthesis. Tourism Review, 65(2), pp.138 - 155.

Kelly, S., Asante, S., Jung, J.C.D., Kesaite, V. and Woo, G., 2016. A Risk Analysis Retrospective on the 2015 Paris Attacks. Working Paper 2016:1. Cambridge Risk Framework series. Cambridge: Centre for Risk Studies University of Cambridge.

Kester, J., 2015. International Tourism Trends in EU28 Member States. Current Situation and Forecasts for 2020-2025-2030, [pdf] Available at: <http://www.eucentre.sg/wpcontent/uploads/2015/08/UNWTO_TT2030_EU28.pdf> [Accessed 26 June 2017].

Leitão, N. and Shahbaz, M., 2012. Migration and Tourism Demand. Theoretical and Applied Economics, 19(2), pp.39-48.

Llorca-Vivero, R., 2008. Terrorism and International Tourism: New Evidence. Defence and Peace Economics, 19(2), pp.169-188.

Mironiuc, M., 2009. Analiză economico-financiară. Performanţă. Poziţie financiară. Risc. Iaşi: Editura Universităţii Alexandru Ioan Cuza.

Peterman, T., Revermann, C. and Scherz, C., 2005. Future Trends in Tourism. Office of Technology Assessment at the German Bundestag, Working Paper, 101.

Robertson, D., Kean, I. and Moore, S., 2006. Tourism Risk Management An Authoritative Guide to Managing Crises in Tourism. [pdf] APEC International Centre for Sustainable Tourism (AICST). Available at: <https://earthcheck.org/media/7635/tourism-riskmanagement.pdf $>$ [Accessed 17 september 2018].

Rode, N.C.W., 2008. The Tourism-Migration Nexus: Towards a Theory of global Human Mobility. Theses and Dissertations, Paper 102. 
Sala-i-Martin, X., 1996. Regional Cohesion: Evidence and Theories of Regional Growth and Convergence. European Economic Review, 40(6), pp.1325-1352.

Sandler, T. and Enders, W., 2008. Economic Consequences of Terrorism in Developed and Developing Countries: An Overview. [pdf] Available at: <http://www.utdallas.edu/ tms063000/website/Econ_Consequences_ms.pdf> [Accessed 5 June 2017].

Schneider, F., Brück, T. and Meierrieks, D., 2011. The Economics of Terrorism and Counter-Terrorism: A Survey (part II), Economics of Security Working Paper 45. Berlin: Economics of Security.

Solow, R.M., 1956. A Contribution to the Theory of Economic Growth. The Quaterly Journal of Economics, 70(1), pp.65-94.

Štetić, S., 2012. Risks in Tourism (On the Example of Events). Quaestus Multidisciplinary Research Journal, 3, pp.68-78.

Tătăruşanu, M., 2016. Turism internaţional. Concepte de bază. Iaşi: Tehnopress.

Tranos, E., Gheasi, M. and Nijkamp, P., 2012. International Migration: A Complex Network. Tinbergen Institute Discussion Paper, 8(123).

University of Maryland, 2017. Global Terrorism Database. [online] Available at: <https://www.start.umd.edu/gtd/> [Accessed 25 June 2017].

Vovk, S., 2015. The Influence of Terrorism on International Tourism. Journal of European Economy, 14(1), pp. 36-48.

Williams, A. and Hall, C.M., 2002. Tourism, migration, circulation and mobility. The contingencies of time and place. [online] Available at: <https://www.researchgate.net/ publication/281560298/download> [Accessed 17 september 2018].

Williams, A.M., 2012. Tourism, Migration and Human Capital: Knowledge and Skills at the Intersection of Flows. In: W.C. Gartner and C. Hsu, eds. 2012. The Routledge Handbook of Tourism Research. London: Routledge, pp. 251-264.

World Bank, 2017. World Development Indicators [online] Available at: $<$ http://databank.worldbank.org/data/reports.aspx? source=world-developmentindicators $>$ [Accessed 25 June 2017].

World Travel \& Tourism Council, 2017. Travel \& Tourism, Economic Impact Denmark. [online] Available at: <https://www.wttc.org/-/media/files/reports/economic-impactresearch/countries-2017/denmark2017.pdf> [Accessed 27 June 2017].

Zaiţ, A., 2006. Convergenţă, divergenţă şi coeziune la nivel UE: delimitări conceptuale şi literature review. Cross-cultural Management Journal, 8(15), pp.1-11.

Yeoman, I., 2011. Tomorrow`s Tourists: Scenarios \& Trends. New York: Routledge. 


\section{ANNEXES}

Annex 1

$\sigma$ convergence countries grouped according to the number of terrorism victims and the number of refugees

\begin{tabular}{|c|r|r|r|r|}
\hline Groups & Group A & Group B & Group C & \multicolumn{1}{c|}{ Group D } \\
\hline $\mathbf{2 0 0 0}$ & 20.36 & 13.12 & 19.50 & 11.77 \\
\hline $\mathbf{2 0 0 1}$ & 20.52 & 13.20 & 19.92 & 11.81 \\
\hline $\mathbf{2 0 0 2}$ & 20.48 & 13.30 & 19.98 & 11.83 \\
\hline $\mathbf{2 0 0 3}$ & 20.71 & 13.47 & 20.35 & 12.00 \\
\hline $\mathbf{2 0 0 4}$ & 21.05 & 13.76 & 20.81 & 12.23 \\
\hline $\mathbf{2 0 0 5}$ & 21.31 & 13.82 & 21.14 & 12.40 \\
\hline $\mathbf{2 0 0 6}$ & 21.62 & 14.04 & 21.33 & 12.81 \\
\hline $\mathbf{2 0 0 7}$ & 21.60 & 14.06 & 21.24 & 13.00 \\
\hline $\mathbf{2 0 0 8}$ & 21.83 & 13.77 & 21.51 & 12.98 \\
\hline $\mathbf{2 0 0 9}$ & 21.88 & 13.75 & 21.36 & 13.21 \\
\hline $\mathbf{2 0 1 0}$ & 21.89 & 13.49 & 21.32 & 12.86 \\
\hline $\mathbf{2 0 1 1}$ & 21.81 & 12.92 & 20.77 & 12.85 \\
\hline $\mathbf{2 0 1 2}$ & 21.64 & 12.62 & 20.12 & 12.92 \\
\hline $\mathbf{2 0 1 3}$ & 21.07 & 12.46 & 19.13 & 12.92 \\
\hline $\mathbf{2 0 1 4}$ & 20.88 & 12.58 & 18.73 & 13.03 \\
\hline $\mathbf{2 0 1 5}$ & 20.88 & 12.98 & 19.04 & 13.21 \\
\hline $\mathbf{2 0 1 6}$ & 20.90 & 13.04 & 19.08 & 13.20 \\
\hline
\end{tabular}

Annex 2

The sensitivity analysis of average GDP in tourism per capita according to the variation of the average number of victims of terrorism and to the dynamics of the average number of international tourist arrivals - the case of the group of $\mathrm{EU}$

\begin{tabular}{|c|c|c|c|c|c|}
\hline Group A & $\begin{array}{l}\text { Index of } \\
\text { average no. } \\
\text { of victims of } \\
\text { terrorism (I } \\
\text { V) }\end{array}$ & $\begin{array}{c}\text { Index of } \\
\text { average no. } \\
\text { of } \\
\text { international } \\
\text { tourist } \\
\text { arrivals (I T) } \\
\end{array}$ & $\begin{array}{l}\text { Index of } \\
\text { average GDP } \\
\text { in tourism } \\
\text { per capita (I } \\
\text { GDPT) }\end{array}$ & $\begin{array}{l}\text { Elasticity of average } \\
\text { no. of international } \\
\text { tourist arrivals in } \\
\text { relation to the average } \\
\text { no. of victims of } \\
\text { terrorism }(\mathrm{E} \mathrm{T} / \mathrm{V})\end{array}$ & $\begin{array}{l}\text { Elasticity of average } \\
\text { GDP in tourism per } \\
\text { capita in relation to the } \\
\text { average no. of } \\
\text { international tourist } \\
\text { arrivals (E GDPT/T) }\end{array}$ \\
\hline 2001 & 1.40 & 0.97 & 1.04 & -0.06 & -1.69 \\
\hline 2002 & 0.00 & 0.99 & 1.04 & 0.0074 & -5.68 \\
\hline 2003 & - & 1.01 & 1.03 & - & 2.45 \\
\hline 2004 & - & 1.07 & 1.05 & - & 0.76 \\
\hline 2005 & - & 1.10 & 1.05 & - & 0.54 \\
\hline 2006 & - & 1.02 & 1.06 & - & 2.63 \\
\hline 2007 & - & 1.03 & 1.07 & - & 2.36 \\
\hline 2008 & 0.44 & 1.00 & 1.04 & -0.0043 & 17.11 \\
\hline 2009 & 3.00 & 0.93 & 0.93 & -0.03 & 0.96 \\
\hline 2010 & 0.33 & 1.03 & 1.04 & -0.05 & 1.10 \\
\hline 2011 & 0.25 & 1.04 & 1.03 & -0.05 & 0.77 \\
\hline 2012 & 0.00 & 1.04 & 1.00 & -0.04 & 0.11 \\
\hline 2013 & - & 1.03 & 1.00 & - & 0.07 \\
\hline 2014 & 0.50 & 1.05 & 1.01 & -0.10 & 0.22 \\
\hline 2015 & 16.00 & 1.06 & 1.02 & 0.0042 & 0.36 \\
\hline
\end{tabular}


Annex 3

The sensitivity analysis of average GDP in tourism per capita according to the variation of the average number of victims of terrorism and to the dynamics of the average number of international tourist arrivals - the case of the group of $\mathbf{E U}$

\begin{tabular}{|c|c|c|c|c|c|}
\hline Group B & $\begin{array}{c}\text { Index of } \\
\text { average no. of } \\
\text { victims of } \\
\text { terrorism(I V) }\end{array}$ & $\begin{array}{c}\text { Index of } \\
\text { average no. } \\
\text { of } \\
\text { international } \\
\text { tourist } \\
\text { arrivals (I T) } \\
\end{array}$ & $\begin{array}{c}\text { Index of } \\
\text { average GDP } \\
\text { in tourism/ } \\
\text { capita (I } \\
\text { GDPT) }\end{array}$ & $\begin{array}{l}\text { Elasticity of average } \\
\text { no. of international } \\
\text { tourist arrivals in } \\
\text { relation to the average } \\
\text { no. of victims of } \\
\text { terrorism }(\mathrm{E} \mathrm{T} / \mathrm{V})\end{array}$ & $\begin{array}{l}\text { Elasticity of average } \\
\text { GDP in tourism per } \\
\text { capita in relation to the } \\
\text { average no. of } \\
\text { international tourist } \\
\text { arrivals }(\mathrm{E} \text { GDPT/T) }\end{array}$ \\
\hline 2001 & 1.07 & 0.98 & 1.05 & -0.14 & -5.23 \\
\hline 2002 & 0.32 & 1.02 & 1.04 & -0.03 & 2.04 \\
\hline 2003 & 1.54 & 1.00 & 1.03 & 0.00 & 18.30 \\
\hline 2004 & 15.39 & 1.02 & 1.05 & 0.0014 & 2.82 \\
\hline 2005 & 0.48 & 1.03 & 1.04 & -0.07 & 1.24 \\
\hline 2006 & 0.03 & 1.06 & 1.06 & -0.06 & 0.97 \\
\hline 2007 & 1.05 & 1.03 & 1.05 & 0.56 & 1.92 \\
\hline 2008 & 2.43 & 0.98 & 1.01 & -0.01 & -0.71 \\
\hline 2009 & 1.22 & 0.95 & 0.94 & -0.19 & 1.27 \\
\hline 2010 & 0.36 & 1.02 & 1.01 & -0.03 & 0.51 \\
\hline 2011 & 0.47 & 1.05 & 1.00 & -0.10 & 0.12 \\
\hline 2012 & 3.15 & 1.01 & 1.00 & 0.0091 & 0.03 \\
\hline 2013 & 1.38 & 1.04 & 0.99 & 0.12 & -0.05 \\
\hline 2014 & 0.42 & 1.04 & 1.02 & -0.08 & 0.44 \\
\hline 2015 & 11.00 & 1.04 & 1.05 & 0.0045 & 1.32 \\
\hline
\end{tabular}

Annex 4

The sensitivity analysis of average GDP in tourism per capita according to the variation of the average number of refugees and to the dynamics of the average number of international tourist arrivals - the case of the group of EU countries with \begin{tabular}{l} 
lower number of refugees (Group C) \\
\hline
\end{tabular}

\begin{tabular}{|c|c|c|c|c|c|}
\hline Group C & $\begin{array}{c}\text { Index of } \\
\text { average no. of } \\
\text { refugees (I R) }\end{array}$ & $\begin{array}{c}\text { Index of } \\
\text { average no. } \\
\text { of } \\
\text { international } \\
\text { tourist } \\
\text { arrivals (I T) }\end{array}$ & $\begin{array}{c}\text { Index of } \\
\text { average GDP } \\
\text { in tourism } \\
\text { per capita (I } \\
\text { GDPT) }\end{array}$ & $\begin{array}{c}\text { Elasticity of average } \\
\text { no. of international } \\
\text { tourist arrivals in } \\
\text { relation to the average } \\
\text { no. of refugees (E T/R) }\end{array}$ & $\begin{array}{c}\text { Elasticity of average } \\
\text { GDP in tourism per } \\
\text { capita in relation to the } \\
\text { average no. of } \\
\text { international tourist } \\
\text { arrivals (E GDPT/R) }\end{array}$ \\
\hline $\mathbf{2 0 0 1}$ & 1.22 & 1.04 & 1.07 & 0.17 & 1.96 \\
\hline $\mathbf{2 0 0 2}$ & 0.84 & 1.01 & 1.06 & -0.09 & 4.34 \\
\hline $\mathbf{2 0 0 3}$ & 1.02 & 1.05 & 1.05 & 2.31 & 0.84 \\
\hline $\mathbf{2 0 0 4}$ & 0.91 & 1.09 & 1.06 & -1.19 & 0.69 \\
\hline $\mathbf{2 0 0 5}$ & 0.69 & 1.01 & 1.07 & -0.04 & 1.35 \\
\hline $\mathbf{2 0 0 6}$ & 0.71 & 1.06 & 1.08 & -0.20 & 1.60 \\
\hline $\mathbf{2 0 0 7}$ & 1.01 & 1.05 & 1.09 & 3.62 & 0.22 \\
\hline $\mathbf{2 0 0 8}$ & 0.90 & 1.04 & 1.05 & -0.45 & 0.78 \\
\hline $\mathbf{2 0 0 9}$ & 0.91 & 0.91 & 0.93 & 1.04 & 0.39 \\
\hline $\mathbf{2 0 1 0}$ & 0.78 & 1.03 & 1.01 & -0.16 & -0.31 \\
\hline $\mathbf{2 0 1 1}$ & 0.94 & 1.07 & 1.02 & -1.22 & -0.08 \\
\hline $\mathbf{2 0 1 2}$ & 1.10 & 1.04 & 0.99 & 0.42 & 0.26 \\
\hline $\mathbf{2 0 1 3}$ & 1.41 & 1.04 & 0.99 & 0.11 & 0.87 \\
\hline $\mathbf{2 0 1 4}$ & 1.30 & 1.05 & 1.01 & 0.18 & 0.04 \\
\hline $\mathbf{2 0 1 5}$ & 2.74 & 1.06 & 1.06 & & \\
\hline
\end{tabular}


Annex 5

The sensitivity analysis of average GDP in tourism per capita according to the variation of the average number of refugees and to the dynamics of the average number of international tourist arrivals - the case of the group of EU countries with

\begin{tabular}{|c|c|c|c|c|c|}
\hline \multicolumn{2}{|c|}{ higher number of refugees (Group D) } \\
\hline Group D & $\begin{array}{c}\text { Index of } \\
\text { average no. of } \\
\text { refugees (I R) }\end{array}$ & $\begin{array}{c}\text { Index of } \\
\text { average no. } \\
\text { of } \\
\text { international } \\
\text { tourist } \\
\text { arrivals (I T) }\end{array}$ & $\begin{array}{c}\text { Index of } \\
\text { average GDP } \\
\text { in tourism } \\
\text { per capita (I } \\
\text { GDPT) }\end{array}$ & $\begin{array}{c}\text { Elasticity of average no. } \\
\text { of international tourist } \\
\text { arrivals in relation to } \\
\text { the average no. of } \\
\text { refugees (E T/R) }\end{array}$ & $\begin{array}{c}\text { Elasticity of average } \\
\text { GDP in tourism per } \\
\text { capita in relation to the } \\
\text { average no. of } \\
\text { international tourist } \\
\text { arrivals (E GDPT/R) }\end{array}$ \\
\hline $\mathbf{2 0 0 1}$ & 1.02 & 0.97 & 1.03 & -0.89 & -1.68 \\
\hline $\mathbf{2 0 0 2}$ & 1.01 & 1.01 & 1.03 & 1.68 & 2.04 \\
\hline $\mathbf{2 0 0 3}$ & 0.79 & 0.99 & 1.02 & 0.02 & -5.51 \\
\hline $\mathbf{2 0 0 4}$ & 0.78 & 1.01 & 1.04 & -0.08 & 2.55 \\
\hline $\mathbf{2 0 0 5}$ & 0.87 & 1.05 & 1.03 & -0.44 & 0.65 \\
\hline $\mathbf{2 0 0 6}$ & 0.85 & 1.05 & 1.05 & -0.39 & 0.95 \\
\hline $\mathbf{2 0 0 7}$ & 1.14 & 1.02 & 1.05 & -0.21 & -0.93 \\
\hline $\mathbf{2 0 0 8}$ & 1.09 & 0.97 & 1.00 & -0.39 & 1.28 \\
\hline $\mathbf{2 0 0 9}$ & 1.10 & 0.95 & 0.94 & 6.22 & 1.41 \\
\hline $\mathbf{2 0 1 0}$ & 1.00 & 1.02 & 1.03 & 0.26 & 0.33 \\
\hline $\mathbf{2 0 1 1}$ & 1.19 & 1.05 & 1.01 & 0.26 & 0.32 \\
\hline $\mathbf{2 0 1 2}$ & 1.08 & 1.02 & 1.00 & 0.15 & 0.05 \\
\hline $\mathbf{2 0 1 3}$ & 1.28 & 1.04 & 1.00 & 0.10 & 0.37 \\
\hline $\mathbf{2 0 1 4}$ & 1.46 & 1.04 & 1.01 & 0.04 & 0.69 \\
\hline $\mathbf{2 0 1 5}$ & 2.08 & 1.04 & 1.03 & & \\
\hline
\end{tabular}

